\title{
POLYMER-BASED MICROSYSTEM FOR MECHANICAL CHARACTERIZATION OF CELLS
}

\author{
M. Gnerlich ${ }^{l}$, W.-Y. Zhang ${ }^{l}$, H. Donahue ${ }^{2}$, A. Voloshin ${ }^{l}$, and S. Tatic-Lucic ${ }^{l}$ \\ ${ }^{1}$ Lehigh University, USA and ${ }^{2}$ Pennsylvania State University, USA
}

\begin{abstract}
A BioMEMS platform has been developed to measure the mechanical compliance of live biological cells. It integrates a Vshaped electrothermal actuator (ETA) array, a force sensor, a displacement sensor, a thermal sensor, and a cell-positioning system in a single chip. By compressing a cell and measuring the reaction force with a biocompatible polymer-based system, the mechanical compliance can be measured without damaging the cell. Here, we present the initial characterizations of the integrated sensors and actuators, as well as temperature measurements during actuation in liquid environments including cell medium.
\end{abstract}

\section{INTRODUCTION}

Determining the mechanical compliance of bone cells is considered to be of paramount importance to research for a more effective cure for osteoporosis, an illness that is impacting a significant portion of the world's senior population [1]. However, there is a lack of accurate and rapid systems that could reliably measure the mechanical properties of multiple biological cells at the same time [2,3], and a BioMEM system has been designed for this purpose. In our previous publications [4,5], we have presented the initial actuator characterization and detailed fabrication process. Here, for the first time, we describe the characterization of all of the constitutive modules, including the temperature measurements in the surrounding cell medium and the preliminary characterization of the force sensor which measures the force exerted onto the cell.

\section{METHOD}

The BioMEM system is illustrated in Fig. 1 and the system functions as follows. First, a cell is trapped in the desired position (between an actuator and a cantilever based force sensor) using a set of four dielectrophoresis (DEP) electrodes stimulated with a 10 $\mathrm{V}_{\mathrm{p}-\mathrm{p}}$ sinusoidal signal at $1 \mathrm{MHz}$. as shown in Fig. 5. Then, a force is applied to the cell using a polymer based electrothermal actuator. The resulting deformation of the cell is measured, and from these two measurements (force and deformation) the Young's modulus can be extracted using the Hertz contact model [6]. The temperature in the area immediately next to the actuator is measured using an integrated platinum resistance temperature detector (RTD) sensor and Wheatstone bridge. The temperature of the surrounding medium was measured using an external type $\mathrm{K}$ bead thermocouple placed $1 \mathrm{~mm}$ from the device and compatible digital multimeter (DMM) with temperature readout.

Power was applied to the actuator as an $800 \mathrm{KHz}$ controlled voltage sinusoidal signal using a high-power operational amplifier. The tests were controlled and measured with a custom LabView program, which allowed integration of the data acquisition from the temperature bridge with GPIB communication to the DMM and function generator instruments. The instantaneous power delivered to the actuator was measured with a 4-point RMS voltage and current setup at 0.5 second intervals and recorded with the temperature data. Optical images were captured at 4 second intervals for displacement measurements using calibrated image capture software.

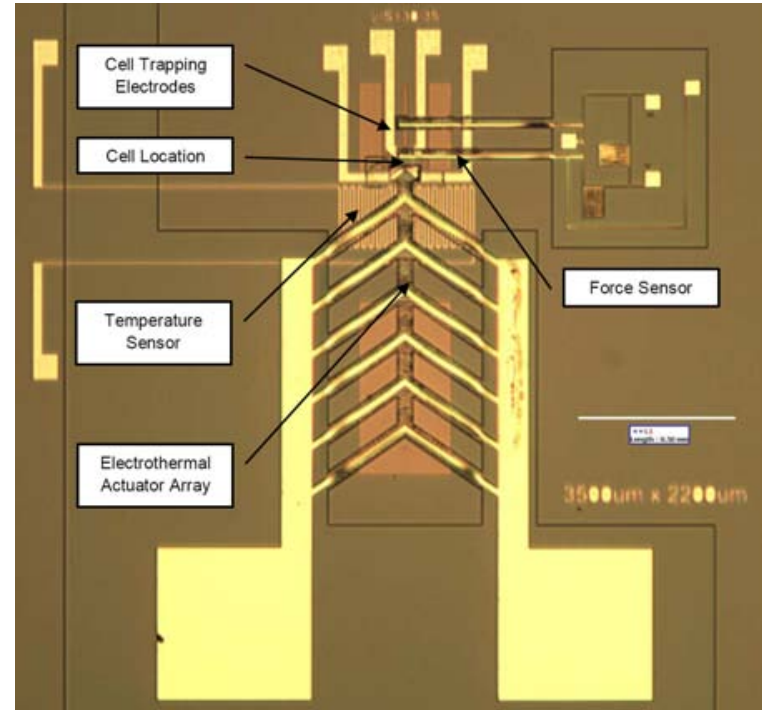

Figure 1. Optical image of a fabricated device with all the constitutive modules (the scale bar is $500 \mu \mathrm{m}$ ) [4]

\section{RESULTS}

The initial characterization of all modules has been completed. The targeted range of up to $4 \mu \mathrm{m}$ motion of the actuator has been reached, as documented on Fig. 2. In addition to the actuator displacement in cell medium, characterization has been performed in three media so far: air, DI water, and cell medium. Temperature during the operation of the actuator has also been measured because we were concerned that the elevated temperature during electrothermal actuation could compromise the health of the living cell.

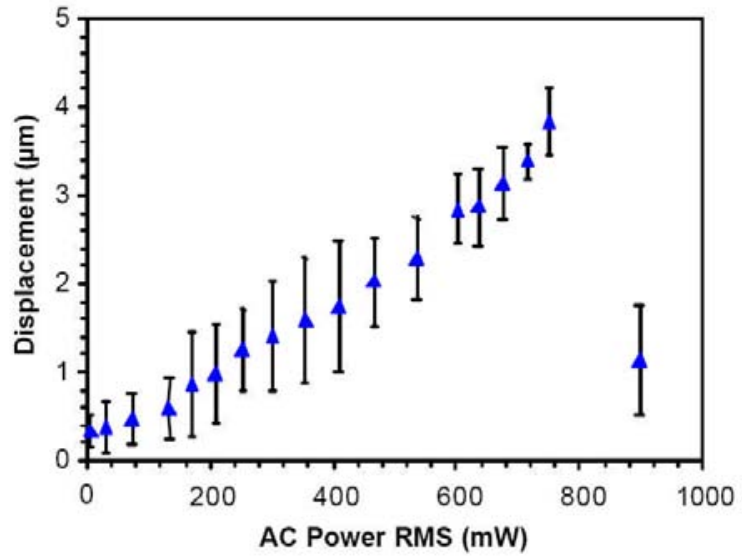

Figure 2. Electrothermal actuator array displacement as a function of applied AC RMS power $(800 \mathrm{kHz})$ in cell medium [5]

The temperature data from the on-chip sensor during 40 second long electrothermal actuator tests in deionized (DI) water shows that the maximum temperature is $45{ }^{\circ} \mathrm{C}\left(+/-2{ }^{\circ} \mathrm{C}\right)$ at the location of the cell at an applied RMS power level of $316 \mathrm{~mW}$, and maximum $51{ }^{\circ} \mathrm{C}\left(+/-2^{\circ} \mathrm{C}\right)$ at an RMS power of $444 \mathrm{~mW}$, as documented on Fig. 3. Using the nearby thermocouple, the 
temperature was measured to be $32{ }^{\circ} \mathrm{C}\left(+/-1^{\circ} \mathrm{C}\right)$ at $316 \mathrm{~mW}$ and 35 $\left(+/-1^{\circ} \mathrm{C}\right)$ at $444 \mathrm{~mW}$. The nominal cell medium temperature at zero power was $1{ }^{\circ} \mathrm{C}\left(+/-1^{\circ} \mathrm{C}\right)$ higher at the end of the test. It was determined that cells would not sustain heat damage during a typical 2.5 second long compression test, since they can withstand temporary $40{ }^{\circ} \mathrm{C}$ temperature elevations above the normal cell culture temperature of $37^{\circ} \mathrm{C}$ [7].
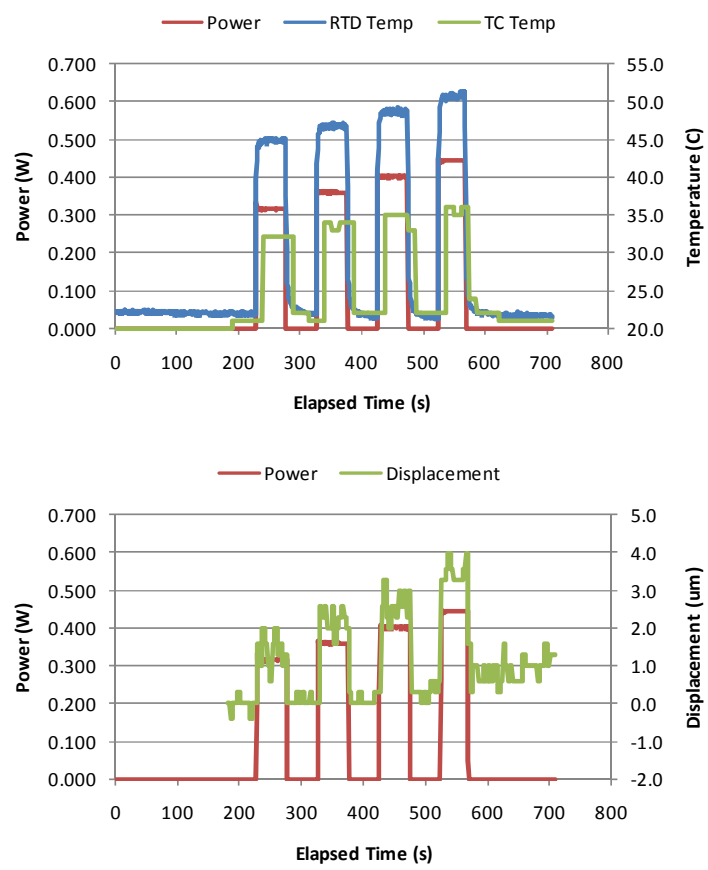

Figure 3. Temperature measured by the on-chip RTD sensor and nearby type $K$ bead thermocouple (top) and corresponding displacement measured optically (bottom) when the actuator is powered in 40 second bursts in deionized water.

Initial characterization results for the force sensor are presented in Fig. 4. We estimate that we can currently resolve a force of $36 \mu \mathrm{N}$ at $1 \mu \mathrm{m}$ displacement for the tested device.

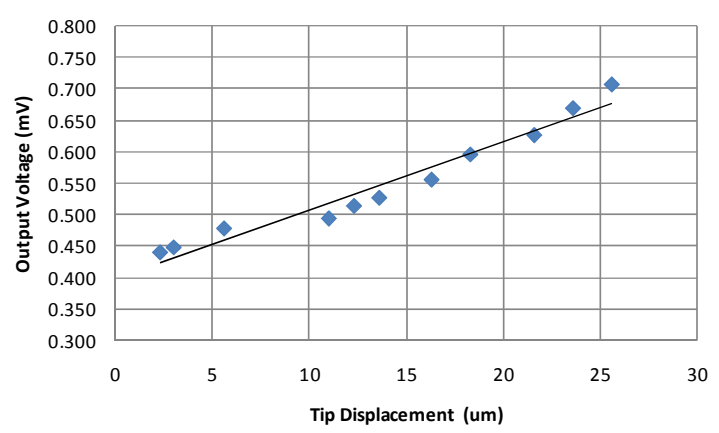

Figure 4. Output voltage as a function of lateral displacement of the cantilever force sensor with integrated Wheatstone's bridge.

In addition to force, measurements of corresponding cell deformation are required to complete mechanical characterization. The original design included a displacement sensor based on a cantilever strain gage attached to the electrothermal actuator array, but its performance was unsatisfactory due to stiction problems and deformation during electrothermal actuation. Therefore, the displacement measurement was performed with an optical microscope requiring only calibration of the image capture software and the achieved optical resolution limit was $+/-0.5 \mu \mathrm{m}$. We have also tested the performance of the cell positioning module, and NIH3T3 fibroblast cells were successfully trapped using the dielectrophoretic electrodes, as documented on Fig. 5 which shows four different snapshots in the cell capturing process.

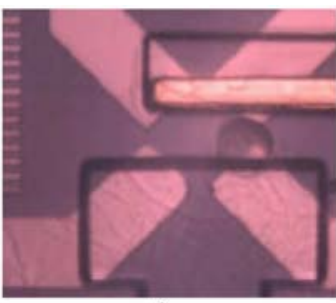

a)

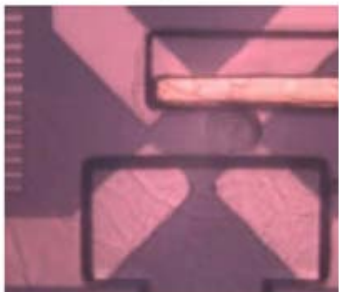

c)

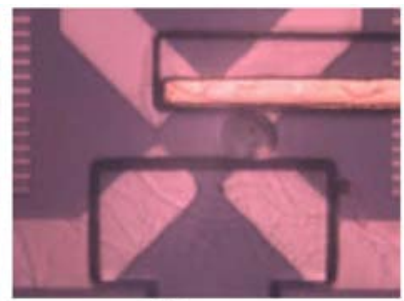

b)

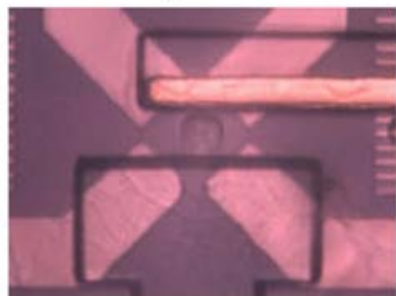

d)
Figure 5. Cell capture with dielectrophoresis electrodes in cell medium. The fibroblast cell is attracted towards the center of the electrodes $(a-c)$ and is kept in place as the cell settles to the bottom of the substrate directly in front of the actuator (d)

\section{CONCLUSION}

Characterization of the components for mechanically testing living cells show that cell trapping, force measurements and electrothermally actuated compression may be accomplished at temperatures suitable for live biological cells while in cell medium. Successful cell compression with physiologically meaningful strain of $25 \%$ has been accomplished, as documented on the cell compression movie [8]. The measurement of mechanical properties of cells is underway.

\section{REFERENCES}

[1] U.S. Department of Health and Human Services. "Bone Health and Osteoporosis: A Report of the Surgeon General" (http://www.surgeongeneral.gov/library/bonehealth/

[2] Miyazaki, H., Hasegawa, Y. and Hayashi, K. "A newly designed tensile tester for cells and its application to fibrobroblasts". J. of Biomechanics, 33 (2000), pp. 97 - 104.

[3] Scuor, N., et al. "Design of a novel MEMS platform for the biaxial stimulation of living cells". Biomedical Microdevices, 8 (2006), pp. 239 - 246.

[4] Zhang, Wenyue, et al. "Polymer MEMS system for measuring the mechanical modulus of a biological cell". BioDevices 2008, 2 (2008), pp. 146 - 150.

[5] Zhang, W.-Y. et al. "Polymer V-Shaped Electrothermal Actuator Array for Biological Applications". Journal of Micromechanics and Microengineering (2008) (submitted).

[6] Zhang, W.-Y. Ph.D. Dissertation. ECE Department, Lehigh University. Bethlehem, PA: Lehigh University, 2007.

[7] Chronis N. and Lee L.P., "Polymer MEMS-Based Microgripper for Single Cell Manipulation”. 17th IEEE International Conference on Micro Electro Mechanical Systems, Maastricht, 1/25 - 1/29 (2004), pp. 17 - 20.

[8] See http://www.lehigh.edu/ mag305/cellcompression/ 